\title{
Research Function of Planning in Administrative Works at Modern Offices
}

\author{
Nguyen Thi Hang* \\ Information Technology and Communication, Thai Nguyen University, Vietnam
}

Submission: September 15, 2019; Published: November 18, 2019

*Corresponding author: Nguyen Thi Hang, Faculty of Economic Information System, Information Technology and Communication, Thai Nguyen University, Vietnam

\begin{abstract}
Today, with the trend of economic and cultural globalization, the focus on administration is an urgent and important job, to build a modern, dynamic and effective public administration. Reducing troubles, an administration taking objects to serve as the main principle and purpose, from which to build, develop and perfect the administration. Office plays an important role in organization and organization. Good office performance will be a tool for development, facilitating the benefits of agency activities. In contrast, poor office performance will lead to many difficulties and fail to achieve the desired effect.

Planning (Planning) is the function of paving the way for the office. Planning is very important, helping the office to predict and gather activities and tasks arranged in a certain order to achieve the goals set. The operation of any agency needs information. Information is a basis for leaders to make timely and accurate decisions. Information includes many types and from many different sources. The leader cannot collect and process all the information on his own, but requires help - that's the office. Office is the "window" is the "filter" of information because all information coming or going is collected, processed, delivered at the office. Therefore, the establishment of plans and plans in the administrative office need to make plans and administrative plans so that administrative procedures can meet the development situation in the congress. enter the globe.
\end{abstract}

Keywords: Planning; Planning functions; Office planning; Office administrative administration; Management decisions

\section{General Reasoning About Office Planning Functions And Related Studies}

Planning is a function of governance that includes activities that define goals for the future and the appropriate means to accomplish those goals. The outcome of the plan is a plan - that is, a written document that clearly identifies the sequence of activities that the company or organization will perform. Planning is the process of defining organizational goals and the best way to achieve those goals. Thus, the planning work in the above sense must include simultaneously two processes of determining goals (what needs to be done?); Identify the path to the goal (how to do it).

Planning is one of the most fundamental and meaningful activities of managers. The concept of planning in general is understood to be the outline and improvement of ideas and projects. Planning is highly strategic and with the development of the organization, the role of this activity is increasingly important. It is the backbone that governs all activities and cultures of an organization. However, a recent study in Harvard Business Review (HBR) shows that only $11 \%$ of big company leaders are happy that strategic planning is worth the effort. This figure does not indicate that the planning of US CEOs is not really effective. In fact in recent decades, there has been a change in the skills and planning methods of US business leaders. This article would like to generalize these two ways for readers to have an overview of how American leaders plan. The ultimate purpose of planning is to set specific goals and methods. In 4 administrative functions, it can be said that Planning is the most important function, because we cannot conduct work without knowing what we want to achieve and what to do to achieve those goals. .

In fact, planning plays a very important role in the business as well as the operation of any other organization. Without poor planning or planning will lead us to heavy failures. Typically, Ford was in the process of launching the Edsel in September 1957. Because of the lack of careful planning, the company went on to make mistakes. That is the name of the model does not attract customers, the time of the market is not appropriate (at that time new models were often sold in November every year), bad design, there are many technical problems. The price is too high 
while customers are targeting cheaper cars, and above all, overpromotion of the car without a market survey. As a result, the Edsel only lasted for four years (from 1957 to 1960) with sales of 60,000 units in the first year, less than $30 \%$ of expectations. Another typical case is P\&G (Procter and Gamble) - the world's leading group of personal care products - that has made false judgments in planning the number of sub-brands of a brand. They think that the more choices for customers, the higher the sales will be. They launched 52 sub-brands of just one Crest toothpaste and 31 sub-brands of a dandruff Head \& Shoulders. Because they have not carefully researched the development plan and strategy for the product, they have pushed their customers against the adversity completely confused by a series of products. As a result, the Crest only accounted for $15 \%$ of the US market share of toothpaste, left behind by Colgate. Therefore, in office work, mastering the principles and planning plan selection is extremely important.

\section{The Basic Roles of Planning for Managers}

In terms of science, the plan is considered a specific action plan, and planning is the process of organizing the preparation and implementation of specific plans that have been proposed. Planning is a process in which an administrator identifies and selects an organization's goals and outlines the actions needed to achieve its goals. Planning is a content and is the most important function of management. Because of this, the plan is tied to the selection and implementation of the future operational programs of an organization, of an enterprise. Planning is also the choice of reasonable approaches to predetermined goals. The plan is to identify goals and decide the best way to achieve your goals.

Planning the plan will help increase the manager's ability to succeed in order to analyze and anticipate opportunities, challenges, difficulties and advantages in the process of achieving goals. Since then, there is a solution to grasp opportunities and limit risks. Through it, will orient the organization's activities, unify thoughts and actions, focusing on key tasks and objectives in each period. This is the basis for the decentralization, the task of implementing the coordination of elements and departments in the organization to actively create tasks and tasks for departments and members in the organization, helping develop declare operational and inspection activities and adjust (goals, activities).

\section{The basic roles of planning for managers include}

First, Planning helps create systematic thinking to predict governance situations. In governance, Planning will help determine the direction of both businesses, companies, and organizations. The administrator - then the captain - must figure out many options to cope with many different situations, because of the uncertainty, the turning of the possibilities is obvious and inevitable. Therefore, careful planning and depth - that is systematic - is something that cannot be overlooked.

Secondly, planning helps to coordinate all efforts of the organization in the process of achieving goals. Planning shows measures to enable maximum exploitation of the enterprise's strengths, take advantage of business opportunities, limit risks for businesses. The planning is dominated by the collective creativity and affection. Decisions made by planning must receive the agreement and smoothness of most members of the organization. Thus, the goals of the organization are achieved.

Third, planning helps focus on goals that avoid waste. Planning should provide a package of measures to enable maximum exploitation of the strength of the business to achieve the goal. Once focusing on the goals, businesses can complete the work with the lowest level of risk and risk possible. Because planning is preparing the organization for better operation in the future.

Fourth, planning will create cooperation and coordination between individuals and departments within the organization. Although planning is the work of individuals (administrators), the goal of this stage is to coordinate the human resources and resources of the whole enterprise in the working process. The work of running the business of a business is always a headache for managers. Each individual, every part of the organization has its own functions and operations, operating in a specific area of expertise, but all are responsible for creating the overall performance of the business. Now, when planning well, managers will know how to coordinate individuals and departments, eliminate internal conflicts, attacks that have long been a threat to the company, tighten The relationship between individuals individuals, individuals - organizations and this department with the other, makes the work smooth.

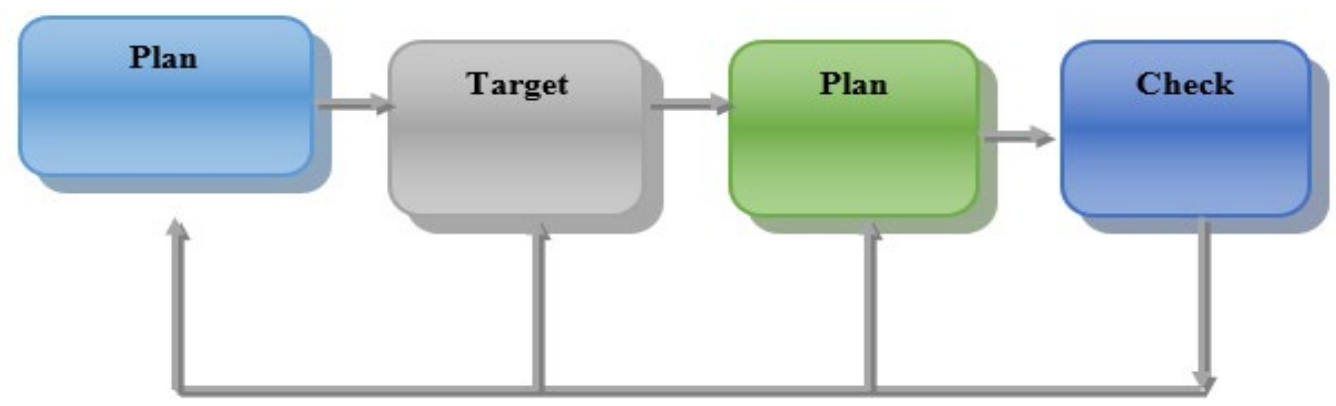

Figure 1: Relationship between planning function in planning. 
Fifth, through planning will increase flexibility and adapt to changes in the external environment. It can be said that in addition to customer factors, many other factors affect the success of businesses. So the Planning process determines the survival of the business before the constant fluctuations of adverse factors. Consideration must be given to the significant deviation between planning and practice so that there is a plan to adjust, making the plan feasible, but it should avoid arbitrary and continuous changes leading to the risk of failing to achieve the item Deficit and failure are certain. The benefits of planning are expressed through the following model (Figure 1).

\section{SWOT Matrix in Office Job Planning}

The SWOT matrix is a very useful tool for capturing and making decisions in any situation with any agency or organization. The SWOT tool component includes:
I. Strengths (Strengths): are agents within agencies, organizations, businesses that are positive or beneficial to help them achieve their goals in setting up their development plans.

II. Weaknesses: are agents inside agencies, organizations, businesses that are negative or cause difficulties in achieving the organization's objectives.

III. Opportunities: Opportunities outside agencies, organizations and businesses (business, social, government) are positive or beneficial to help achieve the goals of the team. function.

IV. Theats (Theats): are agents outside agencies, organizations, businesses (business, social, government,) that are negative or cause difficulties in achieving goals organizations (Table 1).

Table 1: SWOT model in office job planning.

\begin{tabular}{|c|c|c|}
\hline SWOT ANALYSIS & POSITIVE / INCOME In achieving goals & NEGATIVE / HARMFUL In achieving goals \\
\hline INNER PARTNER & STRENGTH & WEAKNESS \\
\hline $\begin{array}{c}\text { (Fact, factors, ... arise from within the organi- } \\
\text { zation) }\end{array}$ & $\begin{array}{l}\text { Need to be maintained, use them as foun- } \\
\text { dation, leverage }\end{array}$ & Need to be repaired, replaced or terminated \\
\hline EXTERNAL WORKERS & OPPORTUNITY & RISK \\
\hline $\begin{array}{l}\text { (The truth, factors, ... arise from the surround- } \\
\text { ing environment) }\end{array}$ & $\begin{array}{c}\text { Need to take advantage, prioritize, catch } \\
\text { in time, build and develop on these } \\
\text { opportunities }\end{array}$ & $\begin{array}{l}\text { These risks need to be included in the plan to develop } \\
\text { organizational, prevention and management options }\end{array}$ \\
\hline
\end{tabular}

The application of SWOT model in office work planning will help the organization to develop a plan to have the unit development direction in all aspects: when there is a development plan, it is possible to estimate the human resources and the business. In fact, ... is directed towards overcoming the backlogs of the previous period, promoting the strengths that have been made, setting out the things to do to bring benefits to the unit, helping the unit go up. This will contribute to saving time and cost: when things need to be done, it will help shorten the time for preparation and implementation. At that time, people were active in the work that they were assigned. Help improve the relationship between people in the unit: everyone in the unit must work together to work together to work towards common goals, helping

\section{Proposing planning process in office administration}

(Figure 2) each other to achieve high results at work. In addition, officials at the agency regularly improve their knowledge to improve their experience and give suggestions to leaders to lead the best goals and plans to be delivered. Organ development increases the likelihood of achieving the desired results with clear goals. Overcome how to do groping, arbitrary, passive deal. Thereby, it will help leaders to be proactive in recognizing opportunities and responding to uncertain factors, events occurring in the process of operation, helping them have a test basis for love. Figure of performing tasks with clear standards, assessing the true results of activities and contributions of each department and individual in the organization.

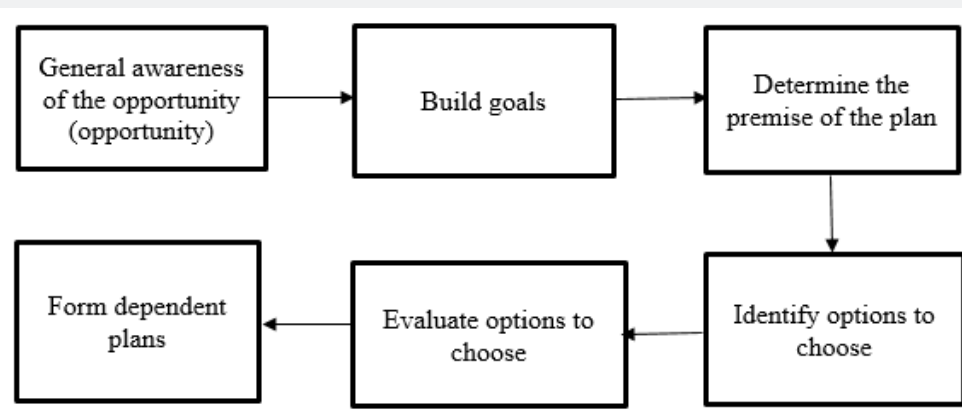

Figure 2: Planning process in office administration. 
Step 1: General awareness of the Olympics: need to carry out specific tasks:
a. Collect information
b. Analysis of general information
c. Results of previous activities
d. Experience in the past
e. Factors and conditions are available

Step 2: Build goals: To plan the first stage, it is necessary to identify the problem:

a. What is the plan to solve?

b. What goal is reached?

c. Why chooses that target?

d. How to do it?

e. Who does it? Ever done?

f. Where to perform?

g. Identify options to choose

h. Identify options to choose

Step 3: Determine the premise of the plan. In order to determine the objectives in order of priority, at the same time determine the guidelines and solutions to implement, besides preparing the contingency plans with the corresponding objectives and solutions.

Step 4: Identify options to choose: List some options, and raise the strengths, weaknesses and necessary conditions when choosing each option. The organization's office prepared to consult the draft plan, outlining many issues that should be focused on obtaining comments on each plan (when necessary and can direct pilot implementation to prove to implementation capacity of each option), outlined the strengths and weaknesses of each option, to finally discuss to select the optimal plan.

\section{Step 5: Evaluate options to choose: Based on the criteria:}

I. Units directly implementing the plan.

II. Superiors, co-managers and some equivalent units.

III. Scientists, experienced people.

IV. Discussion through the draft office administrative plan

V. Rewrite the complete plan after collecting comments

VI. Submit to the higher level for approval

\section{Step 6: Form dependent plans}

I. Prepare documents to issue including plan, appendices if available, instructions for implementation.
II. Develop a propaganda plan, information on plan documents and means for implementation.

III. Estimated plan for implementing the plan.

IV. Expected agencies and departments to implement.

V. The Office submits to the leaders for approval and promulgates the plan together with the above documents to facilitate the implementation of the plan.

\section{Conduct work planning for agencies and organizations} to achieve common goals

Plan the year plan

Source of information from year to year planning includes:

a. From the company's strategy.

b. From participating projects

c. From the company's goals and department objectives assigned by the company.

d. From tasks according to function department functions. Contents of the annual work plan:

a. Content of work objectives.

b. Execution time.

c. The importance of the work (to help the department can focus on any task and evaluate the end of year work).

\section{Plan the month plan}

Source of monthly planning information

a. The work in the year plan.

b. Jobs last month existed.

c. New jobs generated by the company.

Content of the monthly plan

a. Important jobs in the month

b. Part of specific tasks include content of work, implementation time, implementer.

c. The work has not been determined calendar (but must be done in the month or do next month).

\section{Planning week plans}

Information source for week planning:

a. Jobs in the monthly plan.

b. Jobs in the previous week have not been completed

c. New jobs generated by the company.

Content of the week plan

a. Important jobs in the week 
b. Part of specific tasks include content of work, implementation time, implementer, note (requires results).

c. The work has not been determined calendar (but must do it in the week or work in the next week).

\section{Conclusion}

It can be said that planning is to achieve the goal of the organization so the departments and members will focus their attention on achieving this goal and thus agree on all interactions between parts throughout the organization. Planning is the most basic function of an administrator. Planning establishes the foundations and orientations for implementing organizational, leadership, and inspection functions. Helping administrators to actively deal with all future instability related to internal issues such as outside the environment, minimizing uncertainties of the future, focusing on activities to target, reduce costs to increase efficiency. Planning is a powerful tool in coordinating the efforts of members in a business. Planning tells the direction of the business. Thanks to planning, an organization can develop teamwork. When each person in the group works together and knows what he wants to achieve, the results will be higher. Therefore, it is necessary to continue to effectively implement the working regulations of each unit, improve the working regime, enhance the responsibility of the heads of administrative agencies. Formulating regulations and procedures for managing the process of performing tasks of each branch and mass organization in performing tasks, ensuring the management and evaluation of the level of accomplishment of tasks of each cadre and civil servant in unit. There are measures to promote planning in the unit: strict implementation of planning to avoid the implementation of the response. Organizing discussions, propagating about the importance of planning work to all officials and public employees in the unit. Defining clear objectives and plans to attract performers: when the objectives and plans are clear, the security implementers are easily bored and do not want to perform [1-7].

\section{References}

1. Nguyen Van Tham, Luu Kiem Thanh, Le Xuan Lam, Bui Xuan Lu (1999) Guidance on administrative professional techniques, Statistical Publishing House.

2. Nguyen Huu Tri (2005) Office Administration. Science and Technology Publishing House.

3. Dong Thi Thanh Phuong, Nguyen Thi Ngoc An (2005) Administrative Administration Office, Statistical Publishing House.

4. Luong Minh Viet (2005) Secretary of Secretariat. Hanoi Publishing House.

5. Harold Koontz, Cyril Odonnell, Heinz Weihrich (1994) Essential issues of management. Science and Technology Publishing House.

6. James H Donnelly, James L Gibson, John M Ivancevich (2000) Basic Administrator, Statistical Publishing House.

7. Michael E, Porter (2008) Competitive strategy. Statistical Publishing House.

\begin{tabular}{l} 
Your next submission with Juniper Publishers \\
will reach you the below assets \\
- Quality Editorial service \\
- Swift Peer Review \\
- Reprints availability \\
- E-prints Service \\
- Manuscript Podcast for convenient understanding \\
- Global attainment for your research \\
- Manuscript accessibility in different formats \\
( Pdf, E-pub, Full Text, Audio) \\
- Unceasing customer service \\
Track the below URL for one-step submission \\
https://juniperpublishers.com/online-submission.php \\
\hline
\end{tabular}

